\section{Testifying Expert Versus Fact Witness}

Nathalie DeFabrique

Cook County Department of Corrections, Chicago, IL, USA

\section{Synonyms}

Expert witness; Opinion witness

\section{Definition}

An expert witness testifies because he or she has knowledge, skill, experience, training, or education and has expertise that may be meaningful to a party in attempting to prove its side of the case. The expert is not called to testify because of prior involvement in activities that precipitated the litigation. An expert witness testifies voluntarily by agreement with one of the parties or the court. Unlike a fact witness, an expert is entitled to compensation for participation in the case. A key distinction between a fact witness and an expert witness is that an expert witness may provide an opinion. Fact witnesses must limit their testimony to facts in regard to evidence they may have observed or been involved. They may only provide an opinion when the opinion is either based on an actual perception of the witness or might otherwise be helpful to an understanding of their testimony.

\section{Cross-References}

Deposition

\section{References and Reading}

Brodsky, S. L., \& Poythress, N. G. (1985). Expertise on the witness stand: A practitioner's guide. In C. P. Ewing (Ed.), Psychology, psychiatry and the Law: A clinical and forensic handbook.

Melton, G. B., Petrila, J., Poythress, N. G., \& Slobogin, C. (2007). Psychological evaluations for the courts (3rd ed.). New York: Guilford.

Shapiro, D. L. (1984). Psychological evaluation and expert testimony. New York: Van Nostrand Reinhold. 